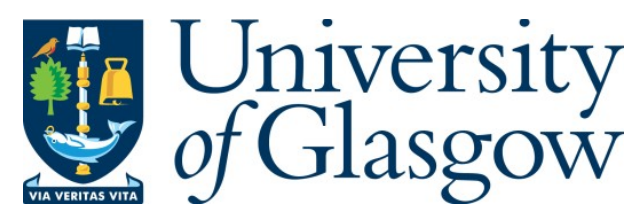

Segnini, E. (2021) From Scampia to Rione Luzzatti: marginality and its language in the age of convergence. Comparative Critical Studies, 18(1), pp. 27-51.

(doi: $10.3366 /$ ccs.2021.0385)

This is the Author Accepted Manuscript which has been accepted for publication by Edinburgh University Press.

There may be differences between this version and the published version. You are advised to consult the publisher's version if you wish to cite from it.

http://eprints.gla.ac.uk/218765/

Deposited on: 22 June 2020

Enlighten - Research publications by members of the University of Glasgow http://eprints.gla.ac.uk 


\title{
From Scampia to Rione Luzzatti: Marginality and its Language in the Age of Convergence
}

\author{
ELISA SEGNINI
}

\section{Abstract:}

\section{Keywords:}

Since conceptualizing a place as marginal presupposes a social, as well as spatial distance between the observer and the observed, marginality must not be taught as a fixed, stable category but as a changeable classification with socio-political connotations. As David Forgacs writes, 'there are no margins, just ways of seeing or observing people and places as marginal'. ${ }^{1}$ One of the ways in which marginality, as a symbolic category, is constructed in fiction is through language. The intersection of language and space has been largely neglected in urban studies, which have given precedence to the visual over the linguistic. ${ }^{2}$ Dialect, however, plays a crucial role in the construction of 'suburb aesthetics' in contemporary Italian fiction, from popular novels to contemporary TV series.

This article aims to provide a framework to examine the language of marginality in the age of convergence, ${ }^{3}$ when best-selling novels have become parts of the phenomenon known as 'branding', and cultural production has become inseparable from the mechanisms that regulate global markets. ${ }^{4}$ It argues that, if the contemporary global novel tends to render the language of the margins implicitly to ensure translatability, the use of non-standard language has become crucial for the construction of marginality on screen for products designed to travel internationally. By focusing on a case study grounded in the Italian context, a comparison between Roberto Saviano's Gomorra 
(2006), with its extensions in theatre, cinema, TV and film parodies, and Elena Ferrante's L'Amica Geniale (2011-14), with its dramatic versions for the radio, the stage and television, it develops a model to compare the intersection of language, space and power in recent examples of transmedia storytelling. Both Saviano's and Ferrante's books focus on the Neapolitan periphery and are concerned with nonstandard language; both are written in standard Italian. In both cases, the process of transmediation involved a shift from a thematic preoccupation with non-standard language to a concrete engagement with Neapolitan. Drawing on studies of multilingualism and marginality, the article addresses the following questions: in what way did linguistic strategies influence the portrayal of the urban periphery as a marginal, subaltern space? How does transmedia transposition, understood as an act of interpretation which 'does not translate the source text in its entirety but makes additions, omissions and changes ${ }^{5}$, relate to interlingual translation? Does the relation between fiction and the socio-linguistic reality represented change in this process? To what ends is dialect deployed in transnational productions designed for global reach, and what characterizes the reception by Italian and international audiences? My focus will be on Italian and Anglo-American cultures, and I will mostly look at adaptations from a distance, focusing on external, extra-textual elements.

\section{LANGUAGE AND URBAN SPACE IN SAVIANO'S GOMORRA AND FERRANTE'S L'AMICA GENIALE}

At first glance, Roberto Saviano's Gomorra and Elena Ferrante's L'amica geniale seems to have little to share. Gomorra (2006) is a hybrid text between journalism and fiction, which alternates accounts of investigations, poetic imagery, memories and reflections as it denounces the operation of the Camorra in Naples and its international ramifications ${ }^{6}$. Elena Ferrante's L'amica Geniale (2011 to 2014) is a Bildungsroman, a tetralogy that follows the lives of two friends, Elena (Lenù) and Raffaella (Lila), from their childhood in the Naples of the 1950s to the present day. While Saviano's book is grounded in facts and concerned with recent events, Ferrante's novels are clearly fictional and span over a larger portion of Italian history. Saviano portrays a male-dominated world, drawing attention to the mechanisms and power struggles that govern the 'System'. Ferrante focuses on the psychology of female figures fighting the gender expectations of the social environment they live in. If we consider the context of production, Saviano's book was published by Mondadori, an established historical publisher part of the Fininvest group; Ferrante's tetralogy was issued by E/O, a more recent, smaller 2 
independent publishing house. On the extra-textual level, Roberto Saviano has become one of Italy's leading media personalities; Elena Ferrante writes under a pseudonym to protect her identity. However, both book series can be characterized as 'glocal': they engage with universal themes - violence, poverty, abuse of power, alliances, revenge - while focusing on a regional dimension, and underline the international resonance of local phenomena. ${ }^{7}$ Both focus on the outskirts of Naples, which they portray as anonymous, self-enclosed spaces characterized by criminality and corruption, separated from the 'centre' in geographical, social and linguistic terms. In Saviano's book, the periphery of Naples is on the one hand a place like any other, where the Camorra is particularly rooted because of the cheap cost of labour, and on the other an epic space, compared to Gomorrah, the city that in the Bible is punished by a rain of fire for the wickedness of its inhabitants. ${ }^{8}$ When Gomorra became a best-seller, readers started conflating the allegorical dimension with factual geography, and the neighbourhoods of Secondigliano and Scampia, from backgrounds of events, became a metaphor of Evil, a 'nonspace'where violence is legitimate and everything is permitted. ${ }^{9}$ In Ferrante's book, the neighbourhood, or rione, as it is called in the narrative, is never named. Its landmarks - a large street, a tunnel, a pond, an elementary school and a local library - could be found in any suburban area. For the Neapolitan novelist Raffaele La Capria, an authoritative voice on the city's cultural scene, the neighbourhood stands for 'qualcosa di malefico, qualcosa che ha a che fare con un destino sciagurato' (something evil, something associated with unfortunate fate) ${ }^{10}$. As the tetralogy became increasingly famous, however, the media pushed for an identification of this space with the rione Luzzatti, in the area of Gianturco, in the Eastern outskirts of Naples. ${ }^{11}$

In both Saviano's text and Ferrante's books, the narrators, which tend to overlap with the authorial persona, are both insiders and outsiders to the marginal worlds they conjure. On the one hand, they stress their familiarity with the Neapolitan outskirts, the indissoluble links to the environment that shaped them; on the other they do not hesitate to condemn it. ${ }^{12}$ This ambivalence finds a correspondence at the stylistic level. In both Gomorra and L'amica geniale, the Neapolitan outskirts are portrayed as linguistic ghettos. In the Italian context, where national unity was achieved only in 1861, at a time in which the majority of Italians where dialect speakers, and the adoption of Italian as a national language was crucial to the construction of the nation-state, the deviation from standard language contributes to the characterization of these territories as outsiders to the state's domain. Linguistic difference, however, does not contaminate the narrative voice. Gomorra is written in standard Italian, in short sentences typical of the language of the media. Saviano dwells on the language of 
the Camorra, but does so to explain it to his readers. ${ }^{13}$ The contemporary jargon of the criminal organization, he demonstrates, builds on dialect, but has incorporated anglicisms, as well as economic and military terms. The text only occasionally resorts to dialect expressions, and, if so, these are mostly recognizable words such as 'munnezza', 'guappo', 'mazziatone'or nicknames like 'o'ntufato' or 'o'mangiavatt', placed into citation marks and juxtaposed to a translation in standard Italian.

Except for a few words, most of which insults (strunz, ricchione, tàmmaro etc), Neapolitan is minimal in Ferrante's tetralogy. The author is, however, deeply invested in dialect at a thematic level. By dwelling on diglossia and, in the last volume, reflecting on the evolution of dialect, she acknowledges that dialect and standard Italian are not fixed, stable languages, and that their boundaries are permeable. On the other hand, in the tetralogy dialect and standard Italian effectively function as markers of separate communities characterized by different geographical provenance and social status. Dialect, Ferrante underlines, is the dominant means of expression in the protagonists' marginal neighbourhood. While this is expected in the 1950, in the tetralogy the situation does not undergo radical changes from generation to generation; the neighbourhood at the centre of the action remains a fairly homogenous community 'isolated

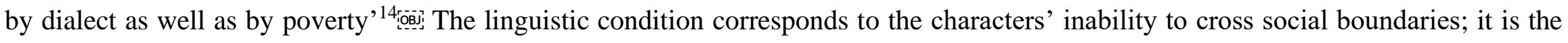
lack of opportunity forces them to be involved with local criminal organizations. Since even characters proficient in standard Italian resort to dialect to intimidate, threaten, and terrorise, Jillian Cavanaugh goes as far as concluding that 'speaking in dialect is frequently a form of violence in and itself in the Neapolitan novels'. ${ }^{15}$ In a review of the fourth volume of the tetralogy, La Capria similarly underlines the relation between dialect, viciousness and aggressiveness: 'Basta sentire come tutti parlano, ed ecco che la ferocia arriva inaspettata, come una zaffata, col dialetto, con una sola frase in dialetto, una frase di una volgarità tremenda, perché cade normalemente e fa crollare il contesto della lingua, ricorda soltanto col suono delle parole che siamo nel rione' (It is sufficient to hear how everyone speaks, and there comes the unexpected ferocity, like a whiff, with dialect, with a single phrase in dialect, a sentence of a terrible vulgarity, that seems normal and makes the context of the language collapse, reminding us that we are in the neighbourhood). ${ }^{16}$

As scholar Brian Lennon notes, in narratives written in the language of the nation-state which engage with multilingualism, stylistic choices carry political meaning. ${ }^{17}$ In Gomorra, the style is in line with the act of rebellion. By placing the jargon of the Camorra into quotes, and translating it into standard Italian, Saviano signals that he is addressing ordinary citizens and that, as a narrator, he is on their 
side. On the other hand, his ability to understand the shades and connotations of this jargon underlines his status as a 'border-line figure' ${ }^{18}$, an insider whose origins and upbringing make him vulnerable to fall pray of the 'System'. Ferrante's novel, as I have argued elsewhere, ${ }^{19}$ can be seen as belonging to the category that Rebecca Walkowitzt describes as 'born translated texts'; texts in which the use of multiple languages is foregrounded thematically or structurally, but does not feature explicitly. ${ }^{20}$ Here, too, the choice of narrating in standard language marks the accrued distance between the narrator and the marginal reality portrayed: Elena (both as author and narrator) ascribes to dialect a negative value and prefers to engage with it from a distance, without quoting it explicitly. As Justin Davidson notes, the tale of the protagonist can also be described as 'the story of a woman changing her speech' ${ }^{21}$. Contributing to the sense of authenticity conjured by the narrative, Ferrante does not hesitate to underline that, as an author, she went through the same linguistic experience as she "changed her speech to a more Northern voice"22.

Sociolinguists insist that the distinction between language and dialect has more to do with socio-political than with linguistic criteria. ${ }^{23}$ A romance language that, in its many variations, is spoken by over seven million people, Neapolitan is not subordinate to standard Italian, but, like other Italian dialects, descends directly from Latin. Because of the large number of speakers, the prestigious history ${ }^{24}$, and the important literary and musical tradition, it is often considered a language. ${ }^{25}$ In Saviano's and Ferrante's books, however, Neapolitan features mostly as the idiom of subalternity and assumes a negative connotation as it is closely bound to violence, abuse and criminality.

\section{MARGINS IN TRANSIT}

As Gomorra and L'Amica Geniale became trans-media phenomena, language played an increasingly central role in the construction of marginality. In Gomorra's case, dialect featured for the first time in the adaptation for the stage directed by Marco Gelardi. Saviano worked with Gelardi on the script as he was revising the book's proofs, and continued the collaboration after the book launch at his native town, Casal di Principe, which led to death threats to the author from exponents of the Casalesi clan. ${ }^{26}$ The play premiered at the Teatro Mercadante, on October 29, 2007, when the book had already become an international phenomenon. Gelardi reduced the number of episodes, foregrounding the ones set in the Neapolitan periphery and in the province of Caserta, and recreated on stage a space 'similar 5 
to Casal di Principe ${ }^{27}$. Using dialect and regional Italian did not prevent the play from touring in other Italian cities, but contributed to grounding the characters in a precise cultural, geographical and social reality. ${ }^{28}$ Saviano's role as author, first-hand witness and narrator was symbolically rendered by the character 'Roberto', interpreted by Ivan Castiglione, who used a different register from the camorristi. By 2009, Gelardi's play had travelled beyond the boundaries of the nation state and premièred in Germany, at Wiesbaden's theatre, in the context of the Theatre biennale festival.

The engagement with dialect continued to grow with the film adaptation by Matteo Garrone (2008). Saviano was again involved in screenplay and played a crucial role in the film's promotion. Like the book, the film could count on experienced distributors. Fandango, a company whose motto is 'to extend the horizon of Italian production on an international scale'29 ensured wide broadcasting nationally and internationally; Rai and Sky disseminated the film through free and pay television. Similarly to the play, the film revolves around five episodes, all set in the Neapolitan periphery or the Casertano, and as in the play, the process of adaptation involved an increased focus on the local, regional dimension of Saviano's investigation. ${ }^{30}$ In Saviano's book, one chapter out of eleven is dedicated to the wars between Camorra clans that took place in Scampia and Secondigliano between 2004 and 2005; in the film, two out of five episodes are set in Scampia, in the Vele housing project, described by Saviano as 'simbolo marcio del delirio architettonico o forse più semplicemente un'utopia di cemento che nulla ha potuto opporre alla costruzione della macchina del narcotraffico che si è innervate sul tessuto sociale di questa parte di terra'(rotten symbol of architectural delirium, or perhaps merely a cement utopia powerless to oppose the narcotraffic machine that feeds on this part of the world). ${ }^{31}$ Through Garrone's gaze, Le Vele gain an imposing visual presence and assume a mythical connotation as 'the objective correlative for the Camorra's sovereign power' ${ }^{32}$ In an interview with Maurizio Braucci, Garrone recalls how he spent several months at the housing project, familiarising with local culture and Camorra aesthetics before beginning the shooting ${ }^{33}$.

While inspired by the book, the film features new characters and develops new story lines. By using inter-cinematic references that play tributes to the masters of neorealism, as well as a surreal aesthetics reminiscent of Tarantino, Garrone projects the story within an international frame of references ${ }^{34}$ In a conversation with Maurizio Braucci, he defends his choices in terms of fidelity to Saviano's style, rather than to mere content: 'E' la stessa cosa che accade in alcune pagine del romanzo di Saviano, che è a metà tra documento e 
romanzo. [...] Le scene di maggior invenzione del film sono, per certi versi, quelle più vere' (It is the same thing that happens in some pages of Saviano's novel, which is halfway between document and novel. ... That the scenes of greatest invention of the film are, in some ways, the truest ones) ${ }^{35}$. Moreover, he emphasizes how, while the film includes elements of social denunciation, the main themes are childhood and adolescence in a marginal geographical, social and psychological space: 'Mi sembra che sia questo il tema centrale del film: il fatto che ci sia un sistema che condiziona, che stritola e che in particolare lo faccia con i più piccoli'(It seems to me that this is the central theme of the film: the fact that there is a system that conditions, that crushes and that this happens in particular with the younger ones). ${ }^{36}$

Garrone's approach, his use of on-site shooting, hand-held camera, and diegetic music have been described by film critics as 'radically realistic, almost documentary-like'. ${ }^{37}$ The sense of authenticity is reinforced by the participation of local, non-professional actors often familiar with or involved with the Camorra, as well as by Saviano's interventions. Even though he could not be present in person at the film's première at Cannes, Saviano contributed by writing an introduction to the film in the official pressbook, which is also summarized in the subtitles that anticipate the credits. Unlike Garrone, he encourages the audience to establish an indexical relationship between the events portrayed on screen and life in the outskirts of Naples as he specifies that the episodes 'si ispirano a fatti realmente accaduti e che continuano ad accadere nei quartieri napoletani come Scampia e nelle zone del Casertano'(are inspired by events that actually happened and that continue to happen in Neapolitan neighbourhoods such as Scampia and in the province of Caserta). ${ }^{38}$ In contrast to the play, the film does not include a narrator-witness, a choice that maximises the space dedicated to dialect at the expense of the rhetorical, testimonial aspect. ${ }^{39}$ In a review published on Il Mattino, La Capria described the language of the film as 'violent and barbaric'and argued that, in being incomprehensible even for educated Neapolitan speakers, it creates a barrier between the audience and the degraded social environment portrayed on screen. ${ }^{40}$ This feature, so crucial in the Italian context, is lost when the film is broadcasted abroad. Like Italian audiences, international spectators watch the film with subtitles. In a sense, it is easy to translate, as foreign subtitles substitute the standard Italian ones, except that international audiences may be unaware of the difference between Italian and the idiom spoken on screen. For a monolingual, English-speaking viewer, the regional and national dimensions are thus conflated at the auditory 
level. ${ }^{41}$ Despite the use of dialect, the film scored record sales in Italy as well as abroad: it was praised in France and the UK, won the Grand Prix at the Cannes Film Festival and was awarded a Golden Globe nomination for Best Foreign Film.

Ferrante's Neapolitan novels had such an impact among Anglophone readers that the first adaptations took place in the UK. When playwright Timberlake Wertenbaker and producer Monica Dolan worked on a BBC drama for Radio 4, they faced the question of how to render the emphasis on Neapolitan in an English-speaking context. Without eliminating Neapolitan references from the narrative - the audience listen to Neapolitan songs, learn about places and food in the city - Wertenbaker had the characters speak in Mancunian, symbolically transposing Naples to Manchester. Explaining her choice, she noted: 'I definitely didn't want them to be from London or the southeast - that would be like setting it in Florence or Milan. Liverpool was right, but too distinctive an accent and place. We wouldn't have dreamt of them speaking with Italian accents..... The only thing that has been a pain is getting the pronunciation of the Italian names right'. ${ }^{42}$ Wertenbaker's strategy, in Lawrence Venuti's terminology, 'domesticates' the text, rendering the experience of the foreign easily accessible to readers in a different culture. ${ }^{43}$ Manchester, in Wertenbaker's view, compares to Naples in being marginal in relation to the capital of the nation state; moreover, Mancunian is associated with the working classes. The device allows a smooth transition from the regional to the international; however, it conflates Naples with its outskirts, and weakens the authenticity conjured by Ferrante's narrative.

Playwright April de Angelis, who adapted L'amica geniale for the stage, aimed to recover the sense of authenticity. Her stage version, which premiered on April 2, 2017 at Kingstone's Rose Theatre, ${ }^{44}$ foregrounds the local dimension, is characterized by 'Mediterranean squalor $^{45}$ and stresses the violence and machism that rules in a neighbourhood controlled by the Camorra. Michael Billington, in a review for The Guardian, notes that the play features 'few likable men'. ${ }^{46}$ Like the novel, it is as much about the complex friendship between two women as about the limits experienced by those raised in a marginal social environment. Following Ferrante's strategy, De Angelis took distance from literal wording and focused on the message conveyed by language choice. When Ferrante, in the books, notes that characters express themselves in dialect, she rendered the language as 'more direct, more coarse, more crude, more colloquial'. When the conversation is supposed to take place in standard Italian, she used 'richer, more rhetorical' English. ${ }^{47}$ To compensate the loss of authenticity conjured by references to dialect in the books, De Angelis stresses that the script was approved by Ferrante, and that 8 
Ferrante's editor, Maurizio dell'Orso, attended rehearsals, 'relying news back to Rome ${ }^{48}$. On stage, in the production directed by Melly Still, the actors speak in their preferred regional accent - Lenù in Irish, her sister in Welsh, the Florentines in Liverpudlian. This device is supposed to anchor the characters to the working classes without faking a Neapolitan accent, which could be perceived as inappropriate and even offensive in an Anglophone context. But it also shifts the play's balance towards the familiar by projecting the story onto a British background.

\section{SUBURBS AESTHETICS AND TRANSNATIONAL CO-PRODUCTIONS}

The TV adaptation of L'amica geniale has often been contrasted to Gomorra-La serie, and marketed as offering a completely different view of Naples. ${ }^{49}$ Despite this, the two products share the features that, according to Massimo Scaglioni, contribute to make a TV series into an international success ${ }^{50}$ : both follow-up international best sellers, are example of quality TV, and take as a model American and British TV. In addition, they involve international partners and are relentlessly advertised on TV networks, social media, and through the use of hashtags. Both scored impressive records at home and abroad. ${ }^{51}$ On Fandango's website, the two shows are advertised next to one another, and they even share some actors - naturally, cast as camorristi. Both series have been described in terms of realism and neorealism, involve local, often non-professional actors and feature Neapolitan dialect.

In the book, Saviano mocks the interest that the Camorra wars triggered among journalists, the sudden attention that, for the first time, seemed to grant to Scampia and Secondigliano 'a real existence', the media's eagerness to film the sail-shaped buildings. He recalls a screenwriter determined to turn this material into a TV show, and sarcastically omits comments. ${ }^{52}$ A decade later, this idea is no longer surreal. Gomorra-La serie (2014-2019) was produced by Sky Italia, Fandango and Cattleya in collaboration with the TV channel La7. ${ }^{53}$ Like American TV series such as The Sopranos or The Wire, Gomorra features exclusively negative characters, anti-heroes with more of less charisma or charming traits, and foregrounds homosocial bonds, as exemplified by the love-hate relationship between the two protagonists, Ciro di Marzio and Genny Savastano. ${ }^{54}$ As in Saviano's book and Garrone's film, particular attention is dedicated to the 
Secondigliano-Scampia feuds, but the show extends up to the present, involving more recent and even contemporary events. It features fictional characters inspired by real models, and follows Camorra dynasties from generation to generation. Despite the use of imagination, authenticity is conjured at the extra-textual level through Saviano's mediation. The author underlines the series' contribution in denouncing the world of the camorra, and uses TV, facebook and twitter to explain the link between the episodes and factual events. ${ }^{55}$ The stars in the series, Salvatore Esposito (Genny Savastano) and Marco D'Amore (Ciro di Marzio), release interviews in which they recall gang fights and stress the 'sixth sense'developed by all of those who share an upbringing in the territories ruled by the Camorra. ${ }^{56}$

As in Garrone's film, the shooting takes place predominantly on site, in zones of high density and crime. Scampia's local authorities accused the producers of emphasizing exclusively the negative aspect of the neighbourhood, and negotiated for Le Vele to feature for a maximum of $5 \%$ of the total filming. ${ }^{57}$ Nevertheless, the sail-shaped buildings play a prominent role as the centre of business for the Savastanos, a fictional family inspired by real camorristi. In a press conference held in 2014, Saviano underlined that 'girare a Scampia era fondamentale'(to shoot in Scampia was crucial) and stressed that the neighbourhood 'è protagonista, è un attore, non è una quinta che puoi ricostruire: è il Dna della serie'(is the protagonist, the actor, it is not a stage set that you can re build: it is the series' Dna). ${ }^{58}$ Like Garrone's film, the TV show also offers an insight into Camorra aesthetics, featuring villas of local bosses seized by the police in Secondigliano and Scampia. 'Authentic'locations alternate with anonymous spaces such as highways and beaches, stairs and bridges.

As Saviano and the Gomorra-team stress, Gomorra - La Serie does not aim to portray Neapolitans; its focus is limited to the Camorra, ${ }^{59}$ however, in the episodes, the world of criminals and ordinary citizens often overlap. A similar conflation occurs between Neapolitan and the jargon of the criminal organization. A compromise between linguistic realism and comprehensibility is reached by mixing dialect and regional Italian, selecting words that 'sound' like dialect but are comprehensible to standard Italian speakers, and by using the same phrases over and over until they become part of the audience's linguistic luggage. The device is not new: it has been used in the TV show inspired by Andrea Camilleri's novels, which ran on Italian TV since 1999 and was broadcasted, with subtitles, in 65 countries. However, in the Montalbano series dialect is spoken also by positive characters, first and foremost by the commissario, whereas in Gomorra-La serie the Italo-Neapolitan hybrid becomes inseparable from the criminal reality it portrays. 
With the exception of the episodes set in Barcelona, Milan, and of few scenes taking place in Honduras, the first two seasons are predominantly monolingual, as Scampia, Secondigliano, Miano and other neighbourhoods of the Neapolitan outskirts remain the centres of action. Issues of translation are limited to the dialogues between the Savastanos and the few characters speaking standard Italian ${ }^{60}$. During his mission in Barcelona, Ciro continues to speak in Neapolitan and uses an interpreter. The situation changes with the third season, which features more characters speaking in standard Italian. In the first episode, Ciro is in Lyulin, a new district of popular housing located in the outskirts of Sophia, portrayed as an 'eastern Scampia', a concrete jungle ridden by poverty and organized crime. A major shift takes place as this monolingual character, who is never heard speaking standard Italian, appears to master Bulgarian. As the season advances, several episodes take place in the historical centre, in the neighbourhood of Forcella, described by Saviano as 'ventre molle di Napoli'(the soft underbelly of Naples), 'ombelico marcio del centro storico'( rotten navel of the old city centre). ${ }^{61}$ By shifting the action from anonymous new districts at the outskirts to historical Naples, the series also offers more stereotypical images of 'Neapolitanness': the characters are shown singing traditional songs, working at the Forcella market, driving their scooters in narrow streets or along the lungo mare, and positioned next to iconic buildings such as the Palazzo dello spagnolo. This tourist imagery is at odds with the series' focus on marginality, but in line with the increasing global success. In the fourth season, the core of events is still the Neapolitan periphery, but margins expand beyond national boundaries, as scenes set in London alternate with those set in Scampia and Secondigliano. Next to this aspect there is the fear that the periphery may take over the centre, the margins spill over the core, an anxiety summarized by Ciro's speech at the end of season three. ${ }^{62}$

According to Ludovica Rampoldi, the writing team for the series spent weeks in Scampia gathering documentation, meeting people and collecting stories. She notes that participating in the project involved learning Neapolitan, which she describes as a 'real language with great expressive potential'. ${ }^{63}$ In contrast, the Neapolitan film critic Fabio Fusco describes the jargon used in the series as 'un napoletano 'sporco', uno slang delle periferie e dei quartieri più difficili che raramente ascolterete nelle zone più centrali e perbene della città'(a 'dirty' Neapolitan, a slang typical of the suborbs and of the most difficult neighbourhoods that you will rarely hear in the most central and decent areas of the city). ${ }^{64}$ Gomorrese is doubtless among the main ingredients of the series' success. ${ }^{65}$ The way the characters speak is crucial for defining their personalities, and functions as an extension of their actions. ${ }^{66}$ Some of the show's popular 11 
expressions, such as 'stà senz pensier!' or 'O sang' se mastica ma nun se sputa' have become mantra among Neapolitan and Italian youth. Producers have been quick to build on this, and included short clips in which the actors offer lessons on slang, idioms, gestures among the extra contents available on Sky and on the show's DVD. Now TV, an on-demand streaming service for Sky, even broadcasted Gomorrese lessons in collaboration with Zanichelli, an established dictionary publisher, to explain the etymology of these expressions. ${ }^{67}$ The collaboration with Zanichellli contributed to the official recognition of Gomorrese, in spite of the criticism of those who saw in it a mix of common places and popular expressions. These developments, however, are limited to the national setting: Gomorrese lessons are not included in the version with English subtitles.

The tetralogy of L'amica geniale has been described as 'the literary equivalent of a TV box-set', a 'noisy, messy soap opera'and a 'feuilleton that seems planned to become a TV fiction'. ${ }^{68}$ When the TV adaptation was announced in 2016, therefore, it did not come as a surprise. Given the success of Elena Ferrante's novels in the US, it was also foreseeable that the adaptation would be an international coproduction. The show, which started in 2018 and is set to continue for four seasons, is produced by Italy's Rai Fiction and US network HBO with Fandango and Wildeside. On Fandango website, Domenico Procacci, the producer of Garrone's Gomorra, introduces the series as an 'Italian and international' ${ }^{69}$ Despite her invisibility, Elena Ferrante was actively involved in the process of promotion. It was Ferrante who, according to the media, appointed Saverio Costanzo as a director, a choice that provoked consternation among her fans, who doubted that a man would be able to render 'the book's deep dive into female interiority' or 'identify with Lila and Lenù's struggle' ${ }^{70}$

In interviews with La Repubblica and with The New York Times, Ferrante confirms that she sent detailed notes on the script for Costanzo and his collaborators. In addition, she notes that she reserved the right to approve the choice of the actors and the stage set ${ }^{71}$. The TV adaptation has often been described in terms of 'faithfulness'to the novel: it follows closely the events described in the books, reproducing entire sections of dialogue, and features a voiceover drawn directly from Ferrante's text. As in Ferrante's novel, the rione, described by the voiceover as 'una realtà fatta di disagio'(a reality made of poverty), 'una voragine da cui era impossibile uscire'(an abyss from which it was impossible to escape), is marginal but central to the action, the core from which all events originate. While the TV series, like the novel, does not explicitly name this space, the official and unofficial paratexts embrace journalists' interpretations in 
identifying it with the rione Luzzatti, described by Costanzo as an anonymous space, 'a place with no meanings, no charm'. ${ }^{72}$ To ensure accuracy, the production designer, Giancarlo Basili, used original material form the 1950s to reconstructed the neighbourhood in an abandoned glass factory in Caserta ${ }^{73}$. We also learn that, like Garrone and the Gomorra team, he spent a week in the rione Luzzatti, familiarizing with the environment, speaking to locals and taking notes. This approach points to an anachronism, since the first season is set in Naples in 1950s- 60s, and betrays an anthropological gaze that conflates the marginal and the backward, positioning the rione as a zone of otherness left behind in history. ${ }^{74}$ The strategy is, however, contributed to the sense of authenticity conjured by the show. Producer Domenico Procacci speaks of a 'new way of doing epic neorealism, ${ }^{\text {,5 }}$, a statement reinforced by scenes that pay tribute to internationally known masters of neorealism like Roberto Rossellini. Thomas Urbain and Severine Rouby, reviewing the show for The Jakarta Post, speak of a 'Near-documentary look at Naples in the 1950s' ${ }^{76}$

Following the assumption that 'everyone is very good at acting in Naples', the actors were mostly selected among Neapolitans. For Costanzo, it's 'a question of DNA'. Neapolitans, he explains, are born actors as they 'have to defend themselves from a very violent city, to put on a mask and represent a character'. The four girls who interpret the protagonists as children and adolescents 'are not coming from bad neighbourhoods; they are not from Gomorrah type of families' but are nevertheless considered good at acting because of their origins ${ }^{77}$. As in Gomorra-La serie, 'authentic' locations alternate with anonymous settings (highways, stairs, the sea, the countryside). And just as in Gomorra - La serie, life in the rione is inseparable from the operations of the Camorra, which offers the only opportunity of survival for local businesses. ${ }^{78}$ The adaptation also emphasizes the power struggles of criminals and of those who try to resist them. 'I counted three separate instances of blood-drawing violence in the episodes 56 minutes'writes Kosin in the American online magazine The Bazaar, and concludes that, in the rione, 'violence is as much a staple of survival as good as water' 79 . 'One had to be very fortunate not to be touched even slightly by violence and its manifestations in Naples', comments Didier Jacob in The Los Angeles Time. ${ }^{80}$ As in the books, violence is closely associated with dialect, whereas Italian becomes the marker of education and the ticket to break free of the neighbourhood.

Unlike the previous adaptations of the novel, the TV series features Neapolitan, a choice that was seen as radical and revolutionary for HBO, who had never produced a series with subtitles. However, by 2018, the American network could count on eminent predecessors, 
among which Netflix's Narcos and Sky's Gomorra. According to Costanzo, the use of Neapolitan was requested by HBO on the ground of historical accuracy: 'Ho chiesto perché una rete americana dovrebbe interessarsi alla precisione di una lingua se il pubblico guardasse la serie con i sottotitoli. Hanno risposto che volevano che la serie fosse autentica' (I asked why an American network should be interested in linguistic precision if the public would watch it with subtitles. They answered that they wanted the series to be authentic). ${ }^{81}$ At the extra-textual level, authenticity was enhanced by the information broadcasted by the media. Ferrante, who elsewhere makes a point that, in learning to change her speech from dialect to standard Italian, she went through the same experience as the protagonist ${ }^{82}$, allegedly stepped in to translate the dialogues into dialects. ${ }^{83}$ The main actors, who are non-Neapolitan speakers, were trained by a dialect coach.

While the TV series builds on the success of Gomorra-La Serie, its language has been contrasted with the 'crafted' Gomorrese. A review published on the Neapolitan online newspaper fanpage.it notes: 'Non si tratta dello stesso napoletano. La lingua partenopea dei dialoghi dell'Amica è ricercata, sintatticamente corretta, è figlia del periodo storico in cui è ambientato il racconto (gli anni Cinquanta) ed è straordinariamente ricca di vocaboli e riferimenti, senza bisogno di metafore ardite o del cupo valore impresso dai camorristi della serie ispirata al libro di Roberto Saviano'(it is not the same Neapolitan. The Neapolitan used in the dialogues of My Brilliant Friend is sophisticated, syntactically correct, it is grounded in the historical period in which the story is set (the Fifties) and is extraordinarily rich in vocabulary and references, without the need for daring metaphors or the gloomy value ascribed by the camorristi of the series inspired by the book by Roberto Saviano) ${ }^{84}$. An article published Identità insorgenti - a publication based in Naples with the mandate of providing a counter narrative in defense of the Italian South - recognizes instead in the idiom of the show the Neapolitan of the margins: 'Non è il napoletano della canzone, né della poesia, è il napoletano lingua degli ultimi, gettati ai margini della storia'(It is not the Neapolitan of songs, nor of poetry, it is the Neapolitan of the poors, thrown on the margins of history). The article's author, Teresa Apicella, confirms that the reconstruction of Neapolitan, as spoken in the 1950s, is convincing, but expresses reservation about the interpreter of the voiceover, Alba Rohwacher: 'L'accento della Rohrwacher, che presumibilmente tenta di avvicinarsi alla cadenza campana, appare difficile da identificare, e in ogni caso non campano'(Rohrwacher presumably tries to imitate the Campano cadence, but her accent is difficult to identify, and at any case does not sound like a Campano accent) ${ }^{85}$. 
If Ferrante, in the novels, ascribes to dialect a negative value, to the extent that she chooses to not engage with it explicitly, the TV show is often perceived by Neapolitan as endorsing and validating Neapolitan. American reviewers tend, in contrast, to follow the books as they comment on the language of the show. Anna North, in a review published on Vox, underlines that 'The language of the show is violent even when the action is not', ${ }^{86}$ while Miranda Popkey, in an article in The Paris Review, stresses the contrast between the 'guttural dialect'in which 'every other syllable is bitten off, every word ends with u'and the careful, proper diction'of Elena as an adult, 'all rounded vowels and crisp consonants'. ${ }^{87}$ These comments betray hat the authors focus on the adaptation as a transposition of the novels, rather than an autonomous product. In some cases, foreign reviews of the episodes that play mainly in Neapolitan indicate that the multilingual dimension of the show went unnoticed and that Neapolitan was conflated with Italian: 'Italian is visceral language' writes Kosin in The Bazaar, 'at once brutal and romantic and often accompanied with physical gesturing of a similar fervour', ${ }^{88}$ and both Lauren Katz, in Vox, and Kelly Lowler is USA today note that 'HBO's My Brilliant Friend is in Italian, with subtitles' ${ }^{89}$

The last episodes of season one leave the rione to introduce the spectator to Ischia and to the historical centre of Naples, against the backdrop of locations like the galleria Umberto, Piazza Plebiscito, Palazzo Gravina, Via Chaia, Posillipo and the lungomare. Following the books, in season 2 the series takes Elena to Pisa and Florence. The national and international setting, however, continues to be juxtaposed to the rione, where Lila remains anchored, and from which Elena cannot sever ties. These developments increase the use of standard Italian and foreign languages on screen, whereas Neapolitan continues to dominate in the neighbourhood.

\section{FANWORKS AND SEQUELS}

The crucial role of language in the Gomorra brand is also reflected the film parodies produced within a national context. Gomorrese is a central ingredient in the web series by the collective The Jackal, 'Gli effetti di Gomorra sulla gente', which went viral on the web. In this product, the characters are so obsessed by the show that they behave like the series' protagonists, and humour is triggered by the use of Camorra jargon in the context of everyday life. Italian scholars have seen in the parody a subversive effect, as it ridicules the mode of expression of the Camorra and re-appropriates Neapolitan as the language of a vast community. ${ }^{90}$ While the show is an international 
phenomenon, the humour of The Jackal remains bound to national borders, unintelligible to foreign viewers. Like Gomorra, L'amica geniale also inspired parodies and fanfiction. The 'Archive of our own', an archive for fanworks that includes fanfiction, as of 2020 lists six works that build on the narrative universe of $L$ 'amica geniale. ${ }^{91}$ Some of these can be considered subversive in their own terms; for example, 'L'Amica crudele' challenges the novels' gender politics by explaining Elena's fascination with Lila in terms of sexual attraction. All these pieces, however, are written in English, and none of them engages with language.

The success of the brand also influenced the authors' production. Saviano's La Paranza dei bambini (2016), which according to Benvenuti can be seen as a sequel to Gomorra, ${ }^{92}$ is the first book by the author to feature substantial quotes in Neapolitan. In the note that conclude the narrative, Saviano describes the dialect of the book as a 'living oral language', transcribed with the help of renowned experts like Nicola de Blasi and Giovanni Turchetta. The brand's fame is such that the novel, despite the challenge of featuring nonstandard language, was translated internationally: it appeared in English in 2016, in Castillian Spanish and Catalan in 2017, in French and Polish in 2018, and in German in 2019. Breaking the established pattern according to which translations into English tend to privilege fluency at the expense of specificity, Antony Shugaar, who translated the novel for Farrar, Straus and Giroux (2016), made the most radical choice by keeping sentences in Neapolitan in the text, marked by italics and followed by a translation into English. Elena Ferrante's L'invenzione occasionale (2019) follows the opposite route, as the texts were first published in English as columns for The Guardian and only subsequently gathered in a collection published in Italian and English in 2019. In Ferrante's La vita bugiarda degli adulti (2019), which like L'amica geniale is based in Naples and features a similar fascination with margins, the emphasis on dialect is as strong as ever, but Neapolitan continues to be quoted implicitly, rather than directly cited.

\section{MARKETING MARGINS}

Both Gomorra and L'amica geniale involve the contradictions that characterize the paradigm of the 'the postcolonial exotic', as theorized by Graham Huggan. On the one hand, by presenting different aspects of Italy from the one known in the international imagery - marginal neighbourhoods and dialect - they unsettle expectations about life in Naples and 'effect a grounded critique of differential relations of 16 
power'. On the other hand, they turn marginality into a cultural commodity. ${ }^{93}$ As Gomorra became a brand, it also encouraged the production of merchandise: clothes and accessories worn by Ciro started a fashion trend; Cards \& Co produced the Cardgame 'Gomorraland', and Neapolitans, defying the so-called 'cattivo gusto', went as far as shaping nativity set figurines after the series' characters ${ }^{94}$. In the case of L'amica geniale, numerous restaurants are producing pizzas dedicated to Elena and Lila. ${ }^{95}$ Moreover, both brands have boosted the tourism industry, leading travellers into historical Naples, but also encouraging them to visit zones of the city that had been left off the tourism map. A quick search on Tripadvisor discloses numerous posts by fan of Gomorra-la Serie seeking advice about visiting Scampia. These travellers may be disappointed to find out that the sail-shaped towers are now empty, and that the housing projects are about to be demolished. However, the decision to preserve one of the building as a museum may have something to do with the visibility that the site achieved through the Gomorra brand. Similarly, 'Ferrante tours' now guide tourists to the 'authentic' Neapolitan experience, taking them around the city to discover the book's locations. Kathryn Bromwich, on The Guardian, discourages tourists from visiting the 'real' Rione Luzzatti, since 'It is too run-down, depressing, and there is also the issue of well-heeled literature enthusiasts gaping at what is still a very deprived area of the city ${ }^{96}$. In contrast, the local community embraced the trend and had a mural featuring the profile of the actors starring in the TV series painted on the wall of the local library. According to Giampero Perrella, president of the Campania region, this is the first of a series of art works designed to guide tourists through the series' settings. As he notes, 'in questo quartiere, diventato 'famoso' per cose negative, grazie a questa serie adesso arrivano anche i turisti'(Thanks to the TV show, now tourists come to visit a neighbourhood so far 'famous' only for negative aspects) ${ }^{97}$.

\section{CONCLUSIONS}

Gomorra and L'amica geniale started off as very different products. However, as the books developed into a brand, inspiring plays, films, TV series, parodies and fan fiction, the two narrative universes became increasingly comparable. Both brands focused on marginality and embraced the contradictions that characterize the postcolonial exotic. In both cases, margins oscillated from a symbolic space to a concrete, measurable territory, and the overarching theme became the effect of a specific socio-economic environment on the actors born 
and raised within it. The affinity between the two brands culminated in the TV series, in which each product gained features that brought it closer to the other: Gomorra-La serie developed fictional storylines; L'amica geniale was praised for historical accuracy. In L'amica geniale, violence took a visual dimension on screen; whereas Gomorra-La serie focused on characters' psychologies. Saviano and Ferrante's approval was essential for recognizing the narrative extensions as part of the brand, and both authors grounded the products in authenticity by linking fiction, personal experience and factual events. The focus remained on the regional, but the economic and symbolic capital of the companies involved in the productions was key for international distribution. It is not a coincidence that the series share producers (Fandango) and even actors (Alessio Gallo). Poniewozik's description of L'amica geniale as 'a drama punctuated by violence'that 'enfolds warring families and shifting alliances'98 could very well apply to Gomorra. So can the idea of 'a kind of ItaloNeapolitan hybrid, colourful but comprehensible', ${ }^{99}$ a strategy through which both series balanced regional authenticity and international appeal.

Translation, whether intersemiotic or interlinguistic, is an act of interpretation that involves a transformation of the original. In the narrative universes of Gomorra and L'amica geniale, transmedia transpositions can be seen as containing translingual translation: Italian into Neapolitan within the national context, and Italian into English and, in some cases, British dialects or accents in an Anglophone setting. Translation strategies have often diverged: the play Gomorra was staged in Italy with actors acting in Neapolitan; whereas the stage adaptation for My Brilliant Friend took place in the UK, with actors using British accents. The success of the products in dialect also had different repercussions on the books that followed the series. In Saviano's case, the success of Gomorrese eventually influenced the author' style, leading to substantial quotations in dialect, whereas Ferrante's adventure into dialect remained limited to the (alleged) translation of the screenplay. In both brands, however, the use of Neapolitan contributed to global appeal. According to Sarah Doole, director of global drama at Freemantle media - the international distributor for L'amica geniale — English speaking audiences are becoming increasingly responsive to programs with subtitles. ${ }^{100}$ Ivar Kahn, head of drama at Nordisk Film \& TV, stresses that 'the more a product is locally grounded and culturally specific, the more chances it has to sound original and new internationally'. ${ }^{101}$ In both cases, the local community either welcomed the use of Neapolitan in the film/ stage/ TV adaptations as a validation of Neapolitan as a language, or re-appropriated it through parody; foreign critics instead mostly read non-standard language as an element of 'fidelity'to the novels' 
narrative universes. Moreover, if for national audiences, the use of Neapolitan signals distance from the values and rules of the nation state, thereby marking difference and specificity; for the monolingual foreign viewer it often metonymically represents the national dimension that it resists. Finally, in both cases, the emphasis on regional languages and dialect has been interpreted as an instrument of naturalism. However, a closer look at the history of reception has underlined that dialect, in these products, is not the transposition a spoken language, but functions a deliberate poetic device. If the classification of an idiom as dialect is not fixed but depends upon sociopolitical criteria, the valence attributed to non-standard language is also not unchangeable, its connotation contingent on reception by different audiences. Reproducing 'authentic' Neapolitan has never been among the aims of Gomorra's producers. ${ }^{102}$ Neapolitan, as used in L'Amica geniale, has instead been marketed as extremely accurate, allegedly the fruit of Ferrante's translations. Paradoxically, it is in this fictional world that authenticity found its highest resonance.

Word literature scholars have stressed that the use of multilingualism in fiction is inversely proportional to international appeal: the more language varieties feature in a book, the less likely it is to become popular in translation. ${ }^{103}$ This principle reflects the global success of bestsellers such as Gomorra and L'amica geniale, in which the use of Neapolitan is minimal, but is not applicable to the international co-productions they inspired, which increasingly use dialect and regional languages to convey authenticity and represent marginality. Moreover, scholars of multilingualism underline that translations of texts worded in more than one language tend to be homogenizing. ${ }^{104}$ In the case of Gomorra and L'amica geniale, however, we have examples of linguistic diversity increasing in adaptations, with regional languages and dialect becoming more crucial to visual media adaptations than within the texts they are based on. If, rather that considering novels as isolated objects, we examine them as part of a narrative universe that includes both transmedia and transnational adaptations, the paradigm of multilingualism in translation needs to be rethought as more complex and multifaceted.

\footnotetext{
${ }^{1}$ David Forgacs, Italy's Margins: Social Exclusion and Nation Formation since 1861. (Cambridge: Cambridge University Press, 2014$)$, p. 6.

${ }^{2}$ Sherry Simon, Cities in Translation. (London and New York: Routledge, 2012), p. 5.

${ }^{3}$ Henry Jenkins. Convergence cultures: Where Old and New Media Collide. (New York, New York University Press, 2006).

${ }^{4}$ See Rebecca Walkowitz, Born Translated: The Contemporary Novel in an Age of World Literature. (New York: Columbia University Press, 2015) and Gisèle

Sapiro, 'Globalization and cultural diversity in the book market: The case of literary translations in the US and in France.' Poetics 38 (2010), $419-439$.

${ }^{5}$ Sirkku Aaltonen, Time-sharing on stage. Drama Translation in Theatre and Society. (Clevedon/Buffalo/Toronto/Sydney, Multilingual Matters, 2000$)$, p. 45. 
${ }^{6}$ Much has been written about the complex relation between fiction and factual reality in Saviano's novel. Wu Ming 1, in a memorandum published in 2008 , called Gomorra an 'unidentified narrative object'(Wu Ming 1, 7). The sociologist Alessandro Dal Lago, in 2010, described it as 'docu/fiction'(36). See also Alberto Casadei, ' 'Gomorra' e il naturalismo 2.0.'. Memoria in noir: un'indagine pluridisciplinare. Edited by Jansen M., Khamal Y. (Bruxelles, Peter Lang, 2010$)$ pp. 107122; Raffaele Donnarumma, Ipermodernità. Dove va la narrativa contemporanea. (Bologna, Il Mulino, 2014); Christian Rivoletti, 'Forma ibrida e logic poetica: il realismo in Gomorra di Roberto Saviano'. Allegoria, 71-72 (2015). 98-116.

${ }^{7}$ As Giuliana Benvenuti has noted in Il Brand Gomorra: dal romanzo alla serie TV. (Bologna: il Mulino, 2017) the Camorra, which plays a dominant role in both series, is itself a locally determined phenomenon that functions on a global scale (p. 38).

${ }^{8}$ See Genesis 19:24. The symbolic configuration of the camorra as 'Gomorra'originates in a sermon originally written for Don Peppino Diana, murdered by the Camorra. (Gomorra 264-265)

${ }^{9}$ See Samuel Ghelli, 'Da Scampia a 'Gomorra': Nell'archivio di Saviano'. Lettere Italiane, 3 (2012). 87-99, p. 97.

${ }^{10}$ Raffaele La Capria. 'Il labirinto nero di Elena Ferrante: A Napoli la vita è un rione infetto'. Corriere della Sera, December $30,2014$.

https://www.corriere.it/cultura/16_marzo_12/elena-ferrante-napoli-rione-romanzo-0-4a76b44c-e855-11e5-9492-dcf601b6eea6.shtml

${ }^{11}$ See, among others, Andrea Esposito, ' 'L'amica geniale' di Elena Ferrante, viaggio nei luoghi del romanzo'fanpage.it, March 8th, 2016.

https://www.fanpage.it/l-amica-geniale-di-elena-ferrante-viaggio-nei-luoghi-del-romanzo-video/; Ann Mah, 'Elena Ferrante's Naples. Then and now.'The New York

Times. January 14, 2016 http://www.nytimes.com/2016/01/17/travel/elena-ferrante-naples.html; Sophia Seymour, 'Elena Ferrante's Naples- a photo essay', The

Guardian, November 7, 2019.

https://www.theguardian.com/travel/2017/nov/07/elena-ferrante-naples-footsteps-my-brilliant-friend-photo-essay

${ }^{12}$ In Gomorra, the narrator underlines that his upbringing in Casal di Principe has marked him, making him vulnerable to fall pay of the 'System'but also capable of understanding its working mechanisms: 'Non sono mai riuscito a sentirmi distante, abbastanza distante da dove sono nato [....] Nascere in certi luoghi significa essere come il cucciolo del cane da caccia che nasce già con l'odore di lepre nel naso'[I've never been able to take enough distance from the place I was born [....].

Being born in certain places means you're like a hunting dog, born with the smell of the hare already in your nose]. (Gomorra. Edizione Oscar Absolute, Milano, Mondadori, 2016,. p. 307. Translation by Virginia Jewiss, London, Pan Books, 2008).

Both Elena, as a narrator, and Ferrante as an author stress the poverty and violence they experienced during their childhood in the Neapolitan outskirts. Echoing

Elena's experience, Ferrante notes: 'I legami con il rione limitano, fanno male, corrompono o dispongono alla corruzione. E il fatto che non si riesca a reciderli, che si propongano oltre ogni loro apparente dissolversi, non è un bene'[The links with the rione limit, hurt, corrupt or make one prone to corruption. And the fact that one cannot cut them off, that they resist beyond their apparent dissolution, is not a good thing'. (Elisa Ferrante, 'Malgrado tutto. Risposte alle domande di Nicola Lagioia.' La Frantumaglia. Elena Ferrante. (Rome: Edizioni e/o, 2016). pp. 354- 370.

${ }^{13}$ His knowledge of this jargon is so precise that Gomorra ended up among the corpus of literary texts used to develop a glossary of the language of the Camorra in the digital library developed by the University of Naples. See Bianchi, Patricia, 'Glossario di Gomorra'. Cultura della legalità e biblioteca digitale sulla camorra.

Università degli studi di Napoli Federico II.

http://www.bibliocamorra.altervista.org/index.php?option=com_content\&view=article\&id=272\&Itemid=111

${ }^{14}$ Justin Davidson. 'The Hidden Meaning behind My Brilliant Friend's Neapolitan Dialect'Volture, December 3, 2018.

https://www.vulture.com/2018/12/my-brilliant-friend-hbo-neapolitan-dialect.html

${ }^{15}$ Jillian Cavanaugh, 'Indexicalities of Language in Ferrante's Neapolitan Novels: Dialect and Italian as Markers of Social Value and Difference'. In The Works of Elena Ferrante, edited by Grace Russo Bullaro and Stephanie Love. (New York: Palgrave Macmillan, 2016), 45-70; p. 49.

${ }^{16}$ Raffaele La Capria, Raffaele 'Il labirinto nero di Elena Ferrante: A Napoli la vita è un rione infetto'.

${ }^{17}$ Brian Lennon, In Babel's Shadow: Multilingual Literatures, Monolingual States. (Minneapolis: University of Minnesota Press, 2010$)$, p.121.

${ }^{18}$ Alberto Casadei, ' 'Gomorra' e il naturalismo 2.0.'. Memoria in noir: un'indagine pluridisciplinare. Edited by Jansen M., Khamal Y. (Bruxelles: Peter Lang,

2010), 107-122; p. 233 
${ }^{19}$ See Elisa Segnini,'Andrea Camilleri's Montalbano and Elena Ferrante's L'amica geniale: the Afterlife of two Glocal Series.'The Translator 24.3 (2018). Doi: 10.1080/13556509.2018.1502607

${ }^{20}$ Rebecca Walkowitz, Born Translated: The Contemporary Novel in an Age of World Literature. (New York: Columbia University Press, 2015$)$, p.15.

${ }^{21}$ Justin Davidson. 'The Hidden Meaning behind My Brilliant Friend's Neapolitan Dialect'Volture, December 3, 2018.

https://www.vulture.com/2018/12/my-brilliant-friend-hbo-neapolitan-dialect.html

${ }^{22}$ See Ariston Anderson, 'Reclusive author Elena Ferrante talks 'My brilliant friend' HBO adaptation'. The Hollywood reporter, October 16, 2018.

${ }^{23}$ Giulio Lepschy, Mother Tongues and Other Reflections on the Italian Language. (Toronto: University of Toronto Press, 2002), p.36.

${ }^{24}$ Neapolitan was the official administrative language during the Spanish domination

${ }^{25}$ UNESCO includes 'South Italian', also mentioned as 'Neapolitan', in the UNESCO Atlas of the World's Languages in Danger.

http://www.unesco.org/languages-atlas/index.php?hl=en\&page=atlasmap

${ }^{26}$ The book launch in Casal di Principe took place on September 23, 2006. As it is well known, Saviano has since then been obliged to live in hiding and travel under the police escort. This lifestyle has not in the least hindered, but rather increased his presence in the media: since the publication of Gomorra, he has frequently appeared on television, written for newspapers, and made an active use of media platforms. The massive attention of the media had the effect of 'freezing'the development of Saviano as an authorial figure, transforming him into an icon of the fight against organized crime, committed to the values and mandate of his first book (See Benvenuti p.170, Ghelli p.96).

${ }^{27}$ Masolino D'Amico, Masolino. ' Gomorra' tra simbolo e bozzetto'. La stampa, October 31, 2007.

http://www.sipario.it/recensioniprosag/item/2210-sipario-recensioni-gomorra.html

${ }^{28}$ Benvenuti, Il Brand Gomorra, 108-109.

${ }^{29}$ See Domenico Procacci's comment at https://www.fandango.it/film/gomorra/

${ }^{30}$ See Pierpaolo De Sanctis, Pierpaolo. 'Da Saviano a Garrone. Oltre lo Specchio: Gomorra visionaria.'Non solo Gomorra: Tutto il cinema di Matteo Garrone, edited by Pierpaolo De Sanctis, Domenico Monetti, Luca Pallanch. (Cantalupo in Sabinae: Edizioni Sabinae, 2008), 35-44, p. 37.

${ }^{31}$ Roberto Saviano, Gomorra, 72.

32 Millicent Marcus, 'Gomorra by Matteo Garrone'. Italian Political Cinema: Public Life, Imaginary, and Identity in Contemporary Italian Film, Edited by Giancarlo Lombardi and Christian Uva. (Oxford-Bern-Berlin, Peter Lang, 2016), 307-318, p.31.

${ }^{33}$ Braucci, Maurizio, 'Gomorra, il film. Conversazione con Matteo Garrone a cura di Maurizio Braucci'. Non solo Gomorra: tutto il cinema di Matteo Garrone Edited by Pierpaolo de Sanctis, Domenico Monetti, Luca Pallanch. (Rome: Edizioni Sabinae, 2008), 65- 76, p.71.

${ }^{34}$ See Pierpaolo Antonello, 'Dispatches from Hell: Matteo Garrone's Gomorrah'. Mafia Movies: a Reader, edited by Dana Renga. (Toronto, University of Toronto Press, 2011). pp.381-2.

${ }^{35}$ Pierpaolo Antonello, 'Dispatches from Hell: Matteo Garrone's Gomorrah', p.72.

${ }^{36}$ Pierpaolo Antonello, 'Dispatches from Hell: Matteo Garrone's Gomorrah', p. 73

${ }^{37}$ See Pierpaolo Antonello, 'Dispatches from Hell: Matteo Garrone's Gomorrah', p. 378, and Millicent Marcus, 'Gomorra by Matteo Garrone', p. 308.

${ }^{38}$ Roberto Saviano, 'L'impero criminale'. Gomorra, Pressbook, cineteca di Bologna, p.5.

http://www.cinetecadibologna.it/website/files/lumiere/ottobre2008/pdf/pressbookgomorra.pdf. See also Dom Holdaway, Dom. 'Osservazioni sulla retorica di

Gomorra.'(Un nuovo cinema politico italiano, vol II, ed. by Luciana Arcangeli, William Hope \& Silvana Serra, Troubador, 2014), 198-210.

${ }^{39}$ Francesco Crispino, in 'Gomorra', Non solo Gomorra: Tutto il cinema di Matteo Garrone, has argued that the witness's gaze is rendered through cinematic means, such as Garrone's use of hand-held camera (p. 49). Moreover, As Millicent Marcus notes in 'Gomorra by Matteo Garrone', the spectator is encouraged to empathize with Roberto, the assistant of the stakeholder, the only character who dares to rebel to the System and who, not incidentally, carries the same name of the author (p.

313). Nevertheless, these devices do not compare to the strong presence of the narrator/witness in both the novel and the film.

${ }^{40}$ Raffaele La Capria. 'Gomorra, il Divo e il contesto', Il Mattino, 16 giugno (2008), 11-12, p.11. 
${ }^{41}$ The conflation is partly compensated by the visual elements; the shots of Le vele, for example, contrast sharply with popular tourist imagery from Italy - an analysis of the role of the visual in conjuring marginality is, however, outside the scope of the article.

${ }^{42}$ See Alex O’Connell, 'Elena Ferrante was more challenging than Tolstoy'The Times, January 12 2017. https://www.thetimes.co.uk/edition/times2/elena-ferrantewas-more-challenging-than-tolstoy-6c7zbq6tf).

${ }^{43}$ Lawrence Venuti, The Translator's Invisibility. A History of Translation. (London and New York: Routledge, 1995). p. 5.

${ }^{44}$ In collaboration with director Melly Still, De Angelis reduced the four books to a two-part, five and half hour play.

${ }^{45}$ Kate Maltby, 'My Brilliant Friend is one brilliant failure'New Statesman, March 12, 2017.

https://www.newstatesman.com/culture/music-theatre/2017/03/my-brilliant-friend-one-brilliant-failure

${ }^{46}$ Michael Billington, 'My Brilliant Friend review- triumphant staging of Elena Ferrante's quartet'The Guardian, March $14,2017$.

https://www.theguardian.com/stage/2017/mar/14/my-brilliant-friend-review-elena-ferrante-quartet-rose-theatre

${ }^{47}$ Laura Freeman, 'How do you distil Elena Ferrante's monumental Neapolitan quartet into four acts over two evenings? Laura Freeman finds out', p.57. https://www.spectator.co.uk/2017/03/how-on-earth-do-you-put-1600-pages-of-elena-ferrante-on-stage/

${ }^{48}$ Laura Freeman, 'How do you distil Elena Ferrante's monumental Neapolitan quartet into four acts over two evenings? Laura Freeman finds out', p. 57.

${ }^{49}$ Karen Bojar, 'HBO's 'My Brilliant Friend' adds to Ferrante original', Dec 28, 2018

http://elenaferrante.com/tv-series/chestnut-hill-local-hbos-my-brilliant-friend-adds-to-ferrante-original/

${ }^{50}$ Massimo Scaglioni, '(Not So) Complex TV. Framing Seriality as a Practice via Contemporary Models of Italian Television Fiction'Mediascapes journal no. 6, 2016, 8-20, p. 15 .

${ }^{51}$ Gomorra show rights have been sold to over 190 territories; L'amica geniale, which debuted in 2018 , by 2019 sold to over 50 countries.

52 'Sognavano di far derivare da Scampia una puntata di un reality dove poter riprendere un omicidio e lo spaccio di droga. Uno sceneggiatore mi diede un dattoloscritto che raccontava una storia di sangue e morte, dove il diavolo del Secolo Nuovo veniva concepito nel rione Terzo Mondo' [They dreamed of making

Scampia into a reality show, with footage of a homicide or drug deal. One scriptwriter told me a story of blood and death, where the devil of the new century is conceived in Terzo Mondo] (Roberto Saviano, Gomorra, p. 136)

${ }^{53}$ German Beta film and other international TV networks also participated in the project, thereby facilitating access to an international market. On the distribution of the product, see Ilaria De Pascalis, 'An Italian Ecosystem: Gomorra'. Reading contemporary serial television Universes: a narrative ecosystem framework, edited by Paola Brembilla and Ilaria A. De Pascalis (London and New York, Routledge 2018), 113- 127, p. 120

${ }^{54}$ See Dana Renga, Watching Sympathetic Perpetrators on Italian Television: Gomorrah and beyond. (London and New York, Palgrave Macmillan, 2009), pp. 257266, and Luca Barra and Massimo Scaglioni. 'Saints, Cops and Camorristi. Editorial Policies and Production Models of Italian TV Fiction.' International Journal of TV Serial Narratives, 1, 2015, 65-76, p.72.

55 On the role of Saviano in mediating between fiction and factual events, see Pierluigi Erbaggio, ' \#GomorraLaSerie: Converging audience and enhanced authorship on twenty-first-century Italian screens.'Modern Italy, 20. 4 (2015), 335-349, p.346. DOI: 10.1080/13532944.2015.1096241

${ }^{56}$ See the articles by Stefano Lo Verme, 'Gomorra, intervista a Marco D'Amore: 'Ciro, antieroe tragico come Iago'Movieplayer June 10, 2014

https://movieplayer.it/articoli/gomorra-intervista-a-marco-damore-ciro-antieroe-tragico-come-iago_12777/ and Alessandro Buttitta, Salvatore Esposito, Genny di

Gomorra: 'Seconda stagione? Forse. A Napoli certe critiche sono strumentali.' Huffington Post, June 2, 2014.. https://www.huffingtonpost.it/2014/06/20/salvatoreesposito-genny-gomorra-intervista-_n 5515299.html. Both articles are mentioned by Dana Renga in Watching Sympathetic Perpetrators on Italian Television.

${ }^{57}$ See Anna D'Ascenzio. 'Un'epica Scampia'. Discorsi su Napoli: rappresentazioni della città tra eccessi e difetti, edited by Stefania Ferraro. Ariccia, Aracne, 2015, pp. 143-172, p.160.

${ }^{58}$ Luca Barra, 'Gomorra - la serie. Il 'senso del luogo' e le frizioni tra produzione e territorio'. Arabeschi no. 13, 2016

http://www.arabeschi.it/31-gomorra---la-serie-vs-scampia-il-senso-del-luogo-e-le-frizioni-tra-produzione-territorio-/

${ }^{59}$ See, for example, the interview with Stefano Lo Verme, 'Gomorra, intervista a Marco D'Amore: 'Ciro, antieroe tragico come Iago' '.

${ }^{60} \mathrm{See}$, for example, the exchanges between Donna Imma and her financial adviser. 
${ }^{61}$ Roberto Saviano, Gomorra, p. 168.

62 The anxiety is summarized in Ciro's last speech at the end of season three.

${ }^{63}$ See the interview with Davide Piacenza, 'Scrivere Gomorra-La Serie'Rivista Studio. (May 9 2016).

https://www.rivistastudio.com/scrivere-gomorra-la-serie/

${ }^{64}$ Fabio Fusco, 'Gomorra: frasi, parole (e maleparole) dagli Stati Uniti di Scampia e Secondigliano'Movieplayer, (June 62016$)$.

https://movieplayer.it/articoli/gomorra-le-migliori-frasi-della-serie_16015/

${ }^{65}$ See Fabio Fusco, 'Gomorra: frasi, parole (e maleparole) dagli Stati Uniti di Scampia e Secondigliano'and Virginia Dara, 'Tra influencer and virilità: le strategie di produzione di Gomorra.'Inside Marketing, November 30, 2017.

https://www.insidemarketing.it/strategie-di-promozione-di-gomorra

${ }^{66}$ See Giammario Di Risio, 'Saviano, il sacro e il dialetto nel 'non luogo' di Gomorra'. Close-up.it, June 3, 2016.

${ }^{67}$ Virginia Dara, 'Tra influencer and virilità: le strategie di produzione di Gomorra.'Inside Marketing, November 30, 2017.

https://www.insidemarketing.it/strategie-di-promozione-di-gomorra/

${ }^{68}$ See Elizabeth Day, 'From page to stage: meet the woman bringing the mysterious Elena Ferrante to life'. The Telegraph, March 1, 2017;

https://www.telegraph.co.uk/women/life/page-stage-meet-woman-bringing-mysterious-elena-ferrante-life/; Lisa Allardice, 'Elena Ferrante My Brilliant Friend: how does the show compare to the books?'The Guardian, Nov. 17, 2018. https://www.theguardian.com/books/2018/nov/17/can-elena-ferrantes-my-brilliant-friend-be-asbrilliant-on-television-; and Raffaele Donnarumma, 'Il Melodramma, l'anti-melodramma, la Storia: sull'amica geniale di Elena Ferrante.'Allegoria XVIII, 73 (2018): $138-147$, p.138.

${ }^{69}$ See Domenico Procacci's note on Fandango's website, 'L'amica geniale diventa serie TV HBO-RAI',

https://www.fandango.it/lamica-geniale-diventa-serie-tv-hbo-rai/

${ }^{70}$ See Eleanor Stanford, Valeriya Safranova and Joshua Barone 'Does HBO’s My Brilliant Friend' Capture The Elena Ferrante Feeling?'The New York Times,

November 19, 2018. https://www.nytimes.com/2018/11/19/arts/television/my-brilliant-friend-elena-ferrante-hbo-episodes-1-and-2.html and Julie Kosin 'Why Isn't a Woman Directing My Brilliant Friend?'The Harper's Bazaar, April 5, 2017. In response to this, and in line with the strategies used by Gomorra's producers, Alice Rohwacher directs several episodes in season 2.

https://www.harpersbazaar.com/culture/art-books-music/a21803/my-brilliant-friend-tv-show-male-director/

${ }^{71}$ See Emre Merve, 'Elena Ferrante Stays out of the picture'The New York Times Magazine. November, issue 4, 2018.

https://www.nytimes.com/2018/10/31/magazine/elena-ferrante-hbo-my-brilliant-friend.html?module=inline; and_Angelo Carotenuto, 'Vi mostro il volto della mia amica geniale.' La Repubblica (October 12, 2018).

https://rep.repubblica.it/pwa/venerdi/2018/10/10/news/elena_ferrante_intervista_1_amica_geniale_serie_tv_saverio_costanzo-208634469/

72 See Costanzo's statement in HBO's video 'My Brilliant Friend: behind the Scenes', https://www.youtube.com/watch?v=p9bjxvtbV8g

${ }^{73}$ Kathryn Bromwich, 'I fell in love with Lila: on the set of Elena Ferrante's my Brilliant Friend'The Guardian (November 11, 2018).

https://www.theguardian.com/books/2018/nov/11/on-the-set-of-elena-ferrante-my-brilliant-friend-tv-adaptation

${ }^{74}$ The use of faded colour is in line with this strategy. Viewers, in fact, watch the neighbourhood as through a glass panel. The role of visual elements in conjuring marginality lies, however, outside the scope of this article, as it deserves to be explored independently.

${ }^{75}$ See Domenico Procacci's note on Fandango's website, 'L'amica geniale diventa serie TV HBO-RAI'.

${ }^{76}$ Urbain, Thomas and Severine Rouby. 'HBO goes the foreign language route with 'My Brilliant Friend'The Jakarta Post, November 19, 2018.

https://www.thejakartapost.com/life/2018/11/19/hbo-goes-the-foreign-language-route-with-my-brilliant-friend.html

${ }^{77}$ See Costanzo's statement in Stephanie Bunbury's article, 'My Brilliant Friend: 'Why me? Asks man ordained to direct Elena Ferrante's novels'Stuff.com (November 15, 2018)

https://www.stuff.co.nz/entertainment/tv-radio/108609875/my-brilliant-friend-why-me-asks-man-ordained-to-direct-elena-ferrantes-novels 
${ }^{78}$ At the end of the first season, Lila and her husband must, for example, ask for help to the Solara brothers, the local camorristi, to sell their shoes in the centre of Naples.

79 Julie Kosin, 'Why Isn’t a Woman Directing My Brilliant Friend?'

https://www.harpersbazaar.com/culture/art-books-music/a21803/my-brilliant-friend-tv-show-male-director/

${ }^{80}$ Didier Jacob, 'In a rare interview, Elena Ferrante describes the writing process behind the Neapolitan novels'Los Angeles Times (May 17,2018)

https://www.latimes.com/books/la-ca-jc-elena-ferrante-interview-20180517-htmlstory.htm

${ }^{81}$ See Davide Turrini, 'L'amica geniale questa sera su Rai1: 10 cose da sapere sull aserie TV tratta dal romanzo di Elena Ferrante'Il fatto quotidiano, November 27, 2018.

https://www.ilfattoquotidiano.it/2018/11/27/lamica-geniale-questa-sera-su-rai1-10-cose-da-sapere-sulla-serie-tv-tratta-dal-romanzo-best-seller-della-misteriosaelena-ferrante/4737570/

${ }^{82}$ See Ariston Anderson, 'Reclusive author Elena Ferrante talks 'My brilliant friend' HBO adaptation'.

${ }^{83}$ Bromwich, Kathryn. 'I fell in love with Lila: on the set of Elena Ferrante's my Brilliant Friend'The Guardian, November 11, 2018.

https://www.theguardian.com/books/2018/nov/11/on-the-set-of-elena-ferrante-my-brilliant-friend-tv-adaptation

${ }^{84}$ Ciro Pellegrini, 'Diciamo grazie a L'Amica Geniale che ci ha fatto riscoprire la lingua napoletana'Napoli. Fanpage.it (December 19, 2018).

https://napoli.fanpage.it/amica-geniale-dialetto-napoletano/

85 Teresa Apicella, 'Il napoletano crudo dell'Amica Geniale ci ha convinti...'Identità Insorgenti (November 27, 2018)

https://www.identitainsorgenti.com/lingua-geniale-il-napoletano-crudo-de-lamica-geniale-ci-ha-convinti-ma-la-voce-narrante-no/

${ }^{86}$ Anna North, 'My Brilliant Friend pulls back the curtain on women's lives. What it reveals is dark and violent'Vox, November 20, 2018.

https://www.vox.com/2018/11/20/18102975/hbo-my-brilliant-friend-elena-ferrante-violence

${ }^{87}$ Miranda Popkey, 'The Faces of Ferrante'The Paris Review (December 10, 2018).

https://www.theparisreview.org/blog/2018/12/10/the-faces-of-ferrante/

${ }^{88}$ Julie Kosin, 'Why Isn’t a Woman Directing My Brilliant Friend?'

https://www.harpersbazaar.com/culture/art-books-music/a21803/my-brilliant-friend-tv-show-male-director/

${ }^{89}$ See Lauren Katz, 'HBO’s My Brilliant Friend Adaptation: Reviews and Recaps'Vox (November 18, 2018).

https://www.vox.com/culture/2018/11/20/18104905/my-brilliant-friend-tv-show-hbo-news-review-episode-recaps and Kelly_Lowler, 'Why HBO's beautiful 'My brilliant Friend' is in Italian, with subtitles.' USA today (November 16, 2018).

https://eu.usatoday.com/story/life/tv/2018/11/16/my-brilliant-friend-review-hbos-ferrante-adaptation-soars-italian/1988122002/

${ }^{90}$ See Angela Maiello, Gomorra - la serie: la famiglia, il potere, lo sguardo del male (Roma: Edizioni Estemporanee, 2016). p..69 and Antonella Napoli and Mario Tirino, 'Senza pensieri: Gomorra - La serie: dal contesto produttivo alle audience della rete, fenomenologia di un processo culturale transmedaile. Mediascape journal 7 (2016):102-114, p. 109.

${ }^{91} \mathrm{https}: / /$ archiveofourown.org/works/search?utf8=\%E2\%9C\%93\&work_search\%5Bquery\%5D=L\%27Amica+geniale

92 Giuliana Benvenuti, Il Brand Gomorra: dal romanzo alla serie TV, p. 143

${ }^{93}$ Graham Huggan. The postcolonial Exotic: Marketing the Margins. London and New York, Routledge, 2001, p. 10.

${ }^{94}$ See Giuliana Benvenuti, Il Brand Gomorra: dal romanzo alla serie TV, p. 184, and Ilaria De Pascalis, 'An Italian Ecosystem: Gomorra', p. 122.

${ }^{95}$ Sophia Seymour, 'Elena Ferrante's Naples- a photo essay', The Guardian, November 7, 2019.

https://www.theguardian.com/travel/2017/nov/07/elena-ferrante-naples-footsteps-my-brilliant-friend-photo-essay

${ }^{96}$ Kathryn Bromwich, 'I fell in love with Lila: on the set of Elena Ferrante's my Brilliant Friend'

${ }^{97}$ Giuseppe Cozzolino, 'Napoli, un murales dedicato a 'L'Amica Geniale' nel Rione Luzzatti.'Napoli.fanpage.it, January 28 th, 2019.

https://napoli.fanpage.it/napoli-un-murales-dedicato-a-lamica-geniale-nel-rione-luzzatti/

${ }_{98}$ James Poniewozik, 'Review: 'My Brilliant Friend' Is an Intimate Epic', The New York Times (Nov. 14, 2018) 
https://www.nytimes.com/2018/11/14/arts/television/my-brilliant-friend-review-hbo.html

${ }^{99}$ Justin Davidson, 'The Hidden Meaning behind My Brilliant Friend's Neapolitan Dialect'

${ }^{100}$ Gregg Goldstein, 'Producers case the next big global thing'Variety 339. 1 (Feb 05, 2018): 74-76, p. 74. ProQuest,

http://ezproxy.lib.gla.ac.uk/login?url=https://search-proquest-com.ezproxy.lib.gla.ac.uk/docview/2002099730?accountid=14540.

${ }^{101}$ Gregg Goldstein, 'Producers case the next big global thing', p. 25

${ }^{102}$ See Giammario Di Risio, 'Saviano, il sacro e il dialetto nel 'non luogo' di Gomorra'

${ }^{103}$ See David Damrosch, What Is World Literature? (Princeton, Princeton University Press, 2003), p. 289 and Emily Apter, Against World Literature: on The Politics of Untranslatability. (London, Verso, 2013).

${ }^{104}$ See Rainier Grutman, 2006. 'Refraction and Recognition. Literary Multilingualism in Translation'. Target 18.1 (2006), 7-47. 